\title{
Relaxin-like factor (RLF) serum concentrations and gubernaculum RLF receptor display in relation to pre- and neonatal development of rats
}

\author{
F. R. Boockfor ${ }^{1}$, G. Fullbright ${ }^{2}$, E. E. Büllesbach ${ }^{2}$ \\ and C. Schwabe ${ }^{2 *}$ \\ ${ }^{1}$ Department of Cell Biology and Anatomy and ${ }^{2}$ Department of Biochemistry and Molecular \\ Biology, Medical University of South Carolina, 173 Ashley Avenue, PO Box 250509, \\ Charleston, SC 29425, USA
}

Deletion of the relaxin-like factor (RLF) gene in mice causes retention of testicles and infertility. The development of a synthetic RLF has made it possible to investigate the events that connect the genomic event and the basic biological responses that cause gonadal positioning. AntiRLF antibodies were raised against synthetic RLF, allowing determination of RLF concentrations during the critical period, testing for RLF receptors on the gubernaculum and exploration of the temporal relationship between receptor display and migration of the testes in developing rats. In male rat pups, serum RLF concentrations were high at day 2 before parturition $\left(2.4 \mathrm{ng} \mathrm{ml}^{-1}\right)$ and decreased sharply just before parturition. Thereafter, males and females had the same low serum concentrations until RLF concentrations began to increase in males only, starting at day $\mathbf{1 0}$ after parturition and continuing until adult RLF concentrations $\left(0.6 \mathrm{ng} \mathrm{ml}^{-1}\right)$ were reached on day 39 after parturi-

\section{Introduction}

The failure of testes to descend into the scrotum is one of the most common disorders of sexual differentiation in humans. This condition, known as cryptorchidism, occurs in $3.5 \%$ of newborn boys, but decreases to $0.5 \%$ at 1 year of age (Scorer, 1964; John Radcliffe Hospital Cryptorchidism Study Group, 1986; Toppari and Kaleva, 1999). Retention of the testes in the abdomen results in infertility and an increased risk of testicular cancer. Surgical intervention prevents infertility but the risk of testicular cancer appears to persist (Pike et al., 1986; Strader et al., 1988; Whitaker, 1988; Møller et al., 1996). In men, the relaxin-like factor (RLF) serum concentrations are higher than in children and post-pubertal females (Büllesbach et al., 1999). This finding is in accordance with the relative amounts of RLF mRNA observed in gonadal tissue in mice (Zimmermann et al., 1997).

*Correspondence

Email: schwabec@musc.edu tion. The testicles are descending into the scrotum during this phase of increasing RLF concentrations and are descended fully by day 19-21 after parturition, before adult hormone concentrations are established. The high prenatal serum RLF concentration coincides with high expression of RLF receptors in the gubernaculum tissue. Competitive binding of RLF per mg of membrane protein prepared from rat gubernacula at various developmental stages showed no increase in receptor density as sexual maturity was reached. Gubernaculum cells in primary culture showed an increased uptake of 5-bromo-2'deoxyuridine in the presence of RLF compared with controls. These studies demonstrate that the synthetic RLF is biologically active and indicate that the cryptorchid phenotype INSL3 ${ }^{-/}$is a direct consequence of defective gubernaculum growth, caused by the absence of RLF during early phases of development.
Adham et al. (1993) discovered an mRNA in pig Leydig cells that encodes an insulin-like structure, Leydig insulinlike peptide (Ley I-L), and the coding gene was denoted INSL3 (Burkhardt et al., 1994). After chemical synthesis of this peptide in our laboratory it became apparent that the structure was similar to that of relaxin and that 'relaxin-like factor' (RLF) would be a more fitting name for the protein encoded by this gene (Büllesbach and Schwabe, 1995).

There are strong indications that RLF plays a major role in testicular development, transport and maintenance. $\mathrm{RLF}^{-/-}$ male mice develop cryptorchidism and are sterile (Nef and Parada, 1999; Zimmermann et al., 1999). The mechanism of action of RLF in females is not known.

Variable levels of RLF mRNA have been detected in ovaries and expression of RLF is cycle-dependent (Bathgate et al., 1996; Roche et al., 1996; Zimmermann et al., 1997). The sites of expression of RLF, which are the corpora lutea (Tashima et al., 1995; Bathgate et al., 1996; Roche et al., 1996) and theca cells (Bathgate et al., 1996; Roche et al., 1996), as well as the location of RLF receptors (Büllesbach and Schwabe, 1995, 1999a), imply a potential physiological 
role for RLF in reproduction and also a functional relatedness to relaxin.

The RLF molecule, synthesized chemically according to the mRNA (Pusch et al., 1996; Zimmermann et al., 1997), allowed investigation of the physiological events and the molecular interactions required for testicular descent in laboratory rats. The use of anti-RLF antibodies raised against synthetic RLF to determine endogenous RLF concentrations in rat sera and the use of ${ }^{125}$-labelled mouse RLF to search for gubernaculum RLF receptors is reported. The relationship between gubernaculum growth, circulating RLF concentrations and migration of testes during fetal and neonatal development of rats is also reported.

\section{Materials and Methods}

\section{Animals}

All procedures were performed under an institutionally approved protocol in accordance with the NIH Guide for Care and Use of Laboratory Animals. Holtzman rats at known stages of pregnancy (Harlan Sprague Dawley Inc., Frederick, MD) were used. Rats obtained at day 15 of pregnancy were housed individually in standard $27 \mathrm{~cm} \times$ $48 \mathrm{~cm}$ clear plastic cages at $22^{\circ} \mathrm{C}$ under a $12 \mathrm{~h}$ light: $12 \mathrm{~h}$ dark cycle with water and rat chow available ad libitum. The day of parturition was designated day 0 and the litter and mother were kept together until the young were weaned at day 21 ; thereafter, males and females were separated and housed in groups ( $n=4$ per group). Animals were killed by $\mathrm{CO}_{2}$ anoxia, decapitated, and trunk blood and gubernaculum tissues were collected for radioimmunoassay and receptor-binding experiments, respectively.

\section{Hormones and tracers}

Human RLF (Büllesbach and Schwabe, 1995), human relaxin (Büllesbach and Schwabe, 1991) and rat relaxin (Büllesbach and Schwabe, 1996) were synthesized chemically. For control synthetic mouse RLF B-chain, synthetic mouse RLF A-chain containing the intrachain disulphide bond, natural bovine insulin (Sigma, St Louis, $\mathrm{MO}$ ) and recombinant human insulin-like growth factor I (IGF-l; Sigma) were used. The method for human RLF synthesis (Büllesbach and Schwabe, 1995) was used to produce mouse RLF, 3-(4-hydroxyphenyl)propionyl(A1) (N(in)formyl) mouse RLF (for tracer preparations), an inactive desB(27-31) human RLF and rat RLF. In general, these RLF molecules are produced by solid-phase synthesis of A- and B-chains, followed by site-specific sequential disulphide bond formation. Selectivity is achieved by protecting sulphydryl groups with reagents that can be removed under different conditions. The synthesis of a tracer required a slight deviation as described below.

The 3-(4-hydroxyphenyl)propionyl(A1) (N(in)formyl) mouse RLF analogue $(10 \mu \mathrm{g})$ was dissolved in $10 \mu \mathrm{l}$ of

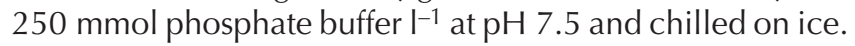

$\mathrm{Na}^{125}$ [I] $(1.8 \mu \mathrm{l}, 0.9 \mathrm{mCi})$ was added, followed by $5 \mu \mathrm{l}$

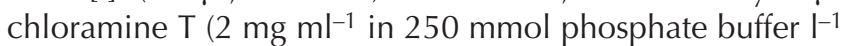
at $\mathrm{pH}$ 7.5). The reaction was performed for $1 \mathrm{~min}$ on ice and the excess of oxidant was reduced with sodium thiosulphate pentahydrate $\left(50 \mathrm{mg} \mathrm{ml}^{-1}\right.$ in $250 \mathrm{mmol}$ phosphate buffer $\mathrm{I}^{-1}$ at $\mathrm{pH}$ 7.5). The $N$ (in)formyl group was removed by exposure to piperidine $(5 \mu \mathrm{l})$ for $2 \mathrm{~min}$; the reaction was acidified with $10 \mu \mathrm{l}$ glacial acetic acid, diluted with $20 \mu \mathrm{l}$ of water and separated by HPLC on an Aquapore 300 $\left(\mathrm{C}_{8}, 2.1 \mathrm{~mm} \times 30 \mathrm{~mm}\right)$ column. The solvent system was $0.1 \%(\mathrm{v} / \mathrm{v})$ trifluoroacetic acid in water (solvent $\mathrm{A})$ and acetonitrile-water-trifluoroacetic acid 80:20:0.1 (v/v/v) (solvent B). Separation was achieved by a 60 min linear gradient from $23 \%$ to $34 \%$ solvent B at a flow rate of $100 \mu \mathrm{l}$ $\mathrm{min}^{-1}$. Proteins were detected by UV absorbance at $230 \mathrm{~nm}$, collected into Eppendorf vials containing $100 \mu \mathrm{l}$ of $1 \%(\mathrm{w} / \mathrm{v})$ aqueous BSA solution, and a $2 \mu \mathrm{l}$ aliquot was assessed in a gamma counter. The calculated molar activity of this

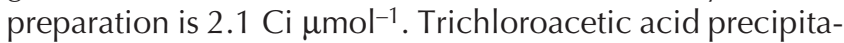
tion $(13 \%(\mathrm{w} / \mathrm{v})$ final concentration) of tracer in $1 \%(\mathrm{w} / \mathrm{v})$ BSA followed by centrifugation at $12000 \mathrm{~g}$ for $10 \mathrm{~min}$ revealed that $<3 \%$ of the radioactivity was found in the supernatant. The mouse RLF tracer was used for the original critical experiments to determine the relative utility of a homologous radioimmunoassay for our studies. It would also be of use for mouse RLF tissue distribution work. In our system it provided no advantage over a previously synthesized human RLF tracer so that routine measurements were done with the easily accessible human RLF tracer labelled in the A9 position (Büllesbach and Schwabe, 1999a).

\section{Polyclonal antibodies}

Antibodies were produced in the Antibody Facility, Medical University of South Carolina. Two rabbits were each injected s.c. with $50 \mu \mathrm{g}$ mouse RLF at monthly intervals. The antibody titre in the serum was determined by radioimmunoassay using goat anti-rabbit IgG conjugated to cellulose to precipitate the tracer-antibody complex.

\section{Serum RLF concentrations in pre-and neonatal rats}

Trunk blood was collected from male rats at selected stages of development, stored on ice and assayed within $24 \mathrm{~h}$ of collection. Each experiment required $250 \mu \mathrm{l}$ rat serum, which was obtained by combining sera from two appropriately age-matched litters of pre- and postnatal male rats up to 4 days of age, one litter of males aged between 10 and 23 days and one male rat aged $>23$ days. Each assay was repeated two more times starting with the same number of animals. Serum was used either undiluted or diluted 1:9 $(\mathrm{v} / \mathrm{v})$ with radioimmunoassay buffer (PBS supplemented with $1 \%(\mathrm{w} / \mathrm{v}) \mathrm{BSA}$ in the presence of $0.01 \%(\mathrm{w} / \mathrm{v})$ sodium azide). Data points obtained in duplicate were compared with a dose-response curve of mouse RLF. For these assays, rabbit anti-mouse antiserum 9956 was used with 125Ilabelled human RLF (20000 c.p.m.) as radioligand 
(Büllesbachet al., 1999). The data from the three independent experiments were pooled and are presented as mean \pm SEM.

\section{Gubernaculum receptor binding assay}

Gubernaculum tissue was collected from male rats at various stages of development and dropped immediately into ice-cold Hepes buffer (25 mmol Hepes I-1, 0.14 mol $\mathrm{NaCl} \mathrm{I}^{-1}, 5.7 \mathrm{mmol} \mathrm{KCl} \mathrm{I-1}, \mathrm{pH} 7.5$, supplemented with 0.25 mol sucrose $\mathrm{I}^{-1}, 0.2 \mathrm{mmol}$ phenylmethylsulfonylfluoride (PMSF) $\mathrm{I}^{-1}$ and $8 \mathrm{mg}$ soybean trypsin inhibitor $\mathrm{I}^{-1}$ ). Gubernaculum tissues of 12 males (two age-matched litters) of pre- or postnatal rats from 2 days before birth to 4 days after birth were pooled into $300 \mu \mathrm{l}$ buffer for analysis. In addition, several experiments were done, each of which used the gubernacula of one litter ( $n=6$ rats) of males aged 10-23 days. The gubernacula were pooled into $600 \mu \mathrm{l}$ buffer and the gubernacula of three male rats aged $>23$ days were also pooled into $600 \mu \mathrm{l}$ buffer.

The tissues were homogenized with a handheld Polytron (PT1200; Brinkmann Instruments, Westbury, NJ) homogenizer at maximum speed for $20 \mathrm{~s}$. The homogenate was centrifuged in an Eppendorf centrifuge (Brinkmann Instruments) at $2000 \mathrm{~g}$ for $10 \mathrm{~min}$ at $4^{\circ} \mathrm{C}$; the pellet was discarded and the supernatant was collected and centrifuged at $14000 \mathrm{~g}$ for $30 \mathrm{~min}$ at $4^{\circ} \mathrm{C}$. The second pellet was resuspended in sucrose-free buffer and centrifuged as before. The resulting pellet was resuspended in binding buffer consisting of $25 \mathrm{mmol}$ Hepes $\mathrm{I}^{-1}, 0.14 \mathrm{~mol} \mathrm{NaCl} \mathrm{I}^{-1}$, $5.7 \mathrm{mmol} \mathrm{KCl} \mathrm{I-1}, 2.8 \mathrm{mmol}$ glucose $\mathrm{I}^{-1}, 25 \mu \mathrm{mol} \mathrm{MgCl}_{2} \mathrm{I}^{-1}$, $1.5 \mathrm{mmol} \mathrm{MnCl}_{2} \mathrm{I}^{-1}, 1.6 \mathrm{mmol} \mathrm{CaCl}_{2} \mathrm{I}^{-1}$ at $\mathrm{pH} 7.5$,

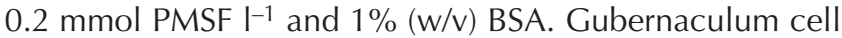
membranes from rats aged $\leqslant 4$ days were suspended in $300 \mu \mathrm{l}$ binding buffer and membrane suspensions from rats aged $>4$ days were reconstituted into $600 \mu$ l binding buffer. For each assay, $20 \mu \mathrm{l}$ tracer (approximately 100000 c.p.m.), $40 \mu \mathrm{l}$ buffer or buffer containing $0.2 \mu \mathrm{g}$ RLF, and $40 \mu \mathrm{l}$ membrane suspension were used. The membrane preparation was incubated for $1 \mathrm{~h}$ at room temperature. Thereafter, the reaction was quenched with $1 \mathrm{ml}$ ice-cold wash buffer

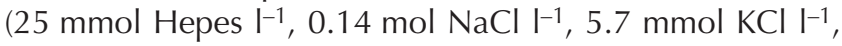
$\mathrm{pH} 7.5$, supplemented with $0.2 \%(\mathrm{w} / \mathrm{v})$ BSA) and centrifuged in an Eppendorf centrifuge for $10 \mathrm{~min}$ at $14000 \mathrm{~g}$ at room temperature. The supernatant was discarded and the tip of the vial was cut and radioactivity was counted in a gamma counter. Gubernaculum RLF receptor densities were determined in duplicate in rats aged $\leqslant 4$ days and in triplicate from rats aged $>4$ days. For each data point, at least three independent experiments, starting with the agematched rats, were performed at weekly intervals. The data were pooled and are presented as means \pm SEM.

For Scatchard analyses (Scatchard, 1949), crude membranes from pooled gubernaculum tissue from five litters of 12-15-day-old males were prepared as described above. The membranes were suspended in $1.5 \mathrm{ml}$ binding buffer. Assays were run in duplicate or triplicate using ${ }^{125} \mid-$ labelled Tyr(A9)human RLF as tracer. Non-specific binding was determined in the presence of $1 \mu \mathrm{g}$ unlabelled human RLF. Protein concentrations were determined using the modified Lowry method adopted for membrane proteins (Markwellet al., 1981). Three sets of animals were used for these assays.

\section{Primary cell culture}

Primary cell cultures from gubernaculum tissue were initiated according to Visser and Heyns (1995). In brief, gubernacula from 3-day-old rats were removed by microdissection and placed into Dulbecco's modified Eagle's medium (DMEM) supplemented with an enzyme solution containing type 1 collagenase $\left(1 \mathrm{mg} \mathrm{ml}^{-1}\right)$ and DNAse-1 (0.13 $\left.\mathrm{mg} \mathrm{m}^{-1}\right)$. The suspension was incubated for $1 \mathrm{~h}$ at $37^{\circ} \mathrm{C}$ with gentle trituration every $15 \mathrm{~min}$. After removal of the enzymes, the cells were filtered through a $25 \mu \mathrm{m}$ filter to remove large cell clumps and transferred to culture flasks. The cultures were grown in 5\% $\mathrm{CO}_{2}$ and $95 \%$ air in DMEM supplemented with fetal calf serum (FCS: 10\% $\mathrm{v} / \mathrm{v}$ ) and $10000 \mathrm{U}$ penicillin-streptomycin $\mathrm{I}^{-1}$. After 1 week, 50000 cells were transferred into each well of a 12-well culture plate, allowed to attach and grown to confluency (2 days).

Receptor binding was measured on intact cells after removing the medium and treating cells with $100 \mu \mathrm{l}$ binding buffer with and without $2 \mu \mathrm{g}$ human RLF, followed by addition of tracer (approximately $2 \times 10^{5}$ c.p.m.). The cells were incubated for $1 \mathrm{~h}$ at room temperature, the buffer was removed, the cells were lysed with $0.1 \mathrm{~mol} \mathrm{NaOH} \mathrm{I}^{-1}$ and the lysates were transferred into counting vials. In each experiment, six data points of total and six data points of non-specific binding were averaged. Three independent experiments were performed, each of which started with a new preparation of primary culture.

\section{Gubernaculum cell growth}

BrdU (5-bromo-2'-deoxyuridine) incorporation in cultured gubernaculum cells was measured to examine the growth factor potential of RLF. Twelve 3-day-old male rats were killed by $\mathrm{CO}_{2}$ inhalation and the gubernacula were excised and collected in DMEM (low glucose and $100 \mathrm{U}$ penicillin-streptomycin $\mathrm{ml}^{-1}$; Gibco, Grand Island, NY). The tissues were cut into $1 \mathrm{~mm}$ pieces with a sterile scalpel, dispersed in a spinner flask and incubated for $1 \mathrm{~h}$ at $37^{\circ} \mathrm{C}$ with sterile filtered medium containing $15 \mathrm{ml}$ low glucose DMEM, $15 \mathrm{mg}$ collagenase type I (Worthington Biochemical Corporation, Lakewood, NJ) and 1.95 mg DNAse I (Sigma). Debris was removed by passage through sterile nylon filters and the cells were collected by centrifugation in a Dynac II (Becton-Dickson, Franklin Lakes, NJ) swinging bucket centrifuge at $300 \mathrm{~g}$ for $10 \mathrm{~min}$. The dispersion media were removed and the cells were rinsed once with culture medium (high glucose DMEM with 10\% (v/v) FBS and $100 \mathrm{U}$ penicillin-streptomycin $\mathrm{ml}^{-1}$ ) (Gibco). Gubernaculum cells (100 000 cells per $\mathrm{ml}$ of culture medium) were plated 


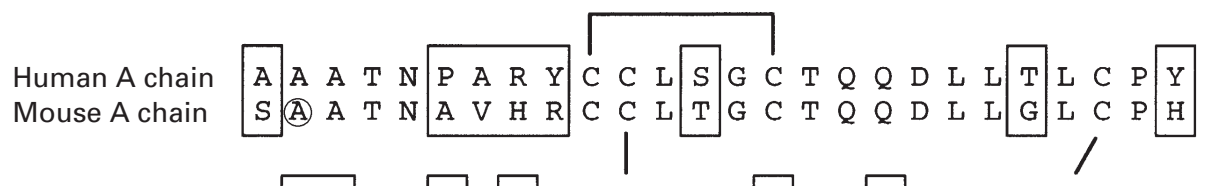

Human B chain Mouse B chain

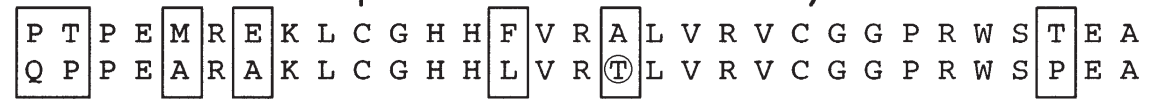

Fig. 1. Primary structure of mouse and human relaxin-like factor (RLF). Boxed-in sequences show the differences between mouse and human RLF, whereas circles indicate residues that differ between rat and mouse RLF.

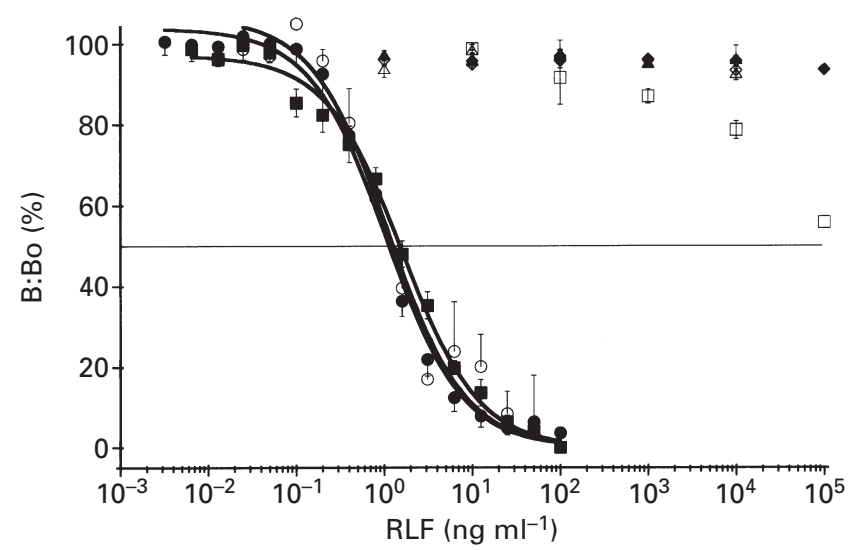

Fig. 2. Radioimmunoassay of rabbit anti-mouse relaxin-like factor (RLF) antibody 9956 using ${ }^{125}$ I-labelled (A9)human RLF as tracer and mouse RLF as competitor. $\bullet$ : Mouse RLF in radioimmunoassay buffer $(n=4 ;-\mathrm{SEM}), \mathrm{ED}_{50}$ value $=1.1 \pm 0.2 \mathrm{ng} \mathrm{ml}^{-1}$. $\bigcirc$ : Mouse $\mathrm{RLF}$ in female rat serum $(n=3 ;+\mathrm{SE}), \mathrm{ED}_{50}$ value $=1.1 \pm 0.39 \mathrm{ng}$ $\mathrm{ml}^{-1}$. $\square$ : Rat $\operatorname{RLF}(n=3 ; \pm \mathrm{SE}) . \square$ : Mouse RLF B chain $(n=2 ;$ \pm SEM). $\diamond$ : Mouse RLF A chain $(n=2 ; \pm \operatorname{SEM}) . \diamond$ : Rat relaxin $(n=2 ;$ $\pm \mathrm{SEM}) . \boldsymbol{\Delta}$ : Bovine insulin $(n=2 ; \pm \mathrm{SEM}) . \triangle$ : Human insulin-like growth factor I $\left(n=2 ; \pm\right.$ SEM). B:B $B_{0}$ : bound:free ligand.

out into six-well culture plates and left for $24 \mathrm{~h}$ in a $\mathrm{CO}_{2}$ incubator at $37^{\circ} \mathrm{C}$. The cells were rinsed once with serumfree culture medium and were treated with $1 \mathrm{ng} \mathrm{ml}^{-1}$ of hRLF, des-(B27-31)hRLF or human relaxin; control wells received no additions. BrdU (Calbiochem, San Diego, CA) was added to a final concentration of $10 \mu \mathrm{mol} \mathrm{\textrm {I } ^ { - 1 }}$ and the cells were incubated for an additional $18 \mathrm{~h}$. The cells were taken up with trypsin-EDTA (Gibco), attached to poly-L-lysinecoated (Sigma) slides, and the BrdU incorporation was measured using a staining kit from Zymed Laboratories Inc. (San Francisco, CA). Starting with the preparation of the primary cell culture, BrdU uptake was measured in seven independent experiments. Each data point was collected in duplicate and data were normalized to the control experiment $(=100 \%)$.

\section{Statistical analysis}

Statistical significance was evaluated by paired analysis using the $t$ test for correlated samples. Statistical significance of the RLF concentration in serum and receptor

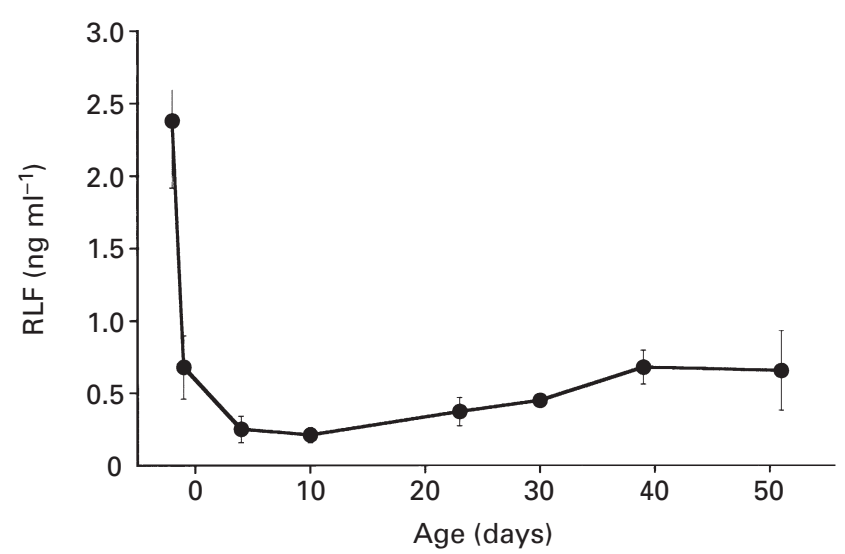

Fig. 3. Relaxin-like factor (RLF) concentrations in $100 \mu \mathrm{l}$ male rat serum during development. Rabbit anti-mouse antiserum 9956 was used in combination with 125/-labelled human RLF as radioligand. Each data point was collected in duplicate and three independent assays were averaged. Data are mean \pm SEM. The data were compared with a mouse RLF standard curve (see Fig. 2).

concentrations at day 2 before parturition was evaluated by one-way ANOVA followed by Newman-Keuls multiple comparison test.

\section{Results}

The differences in the sequences of RLFs between species are not as great as the variability in relaxin sequences. The primary structures of human and mouse RLF are shown (Fig. 1). It was important to determine whether the structural differences, however small, would cause functional differences in the mouse system if human and mouse RLF were used interchangeably. Mouse RLF was synthesized by the methods used for human RLF (Büllesbach and Schwabe, 1995). As mouse RLF does not contain tyrosine, the mouse RLF A-chain was synthesized with a des-aminotyrosyl extension at the $\mathrm{N}$-terminal and combined with a B-chain in which the $\operatorname{Trp}(B 27)$ had been protected against the oxidative iodination conditions. Radioactive iodine was introduced by the chloramine-T method (Hunter and Greenwood, 1962) and the tryptophan-protecting formyl group was removed to complete the mouse RLF tracer synthesis. It was important to purify RLF tracers by HPLC as 


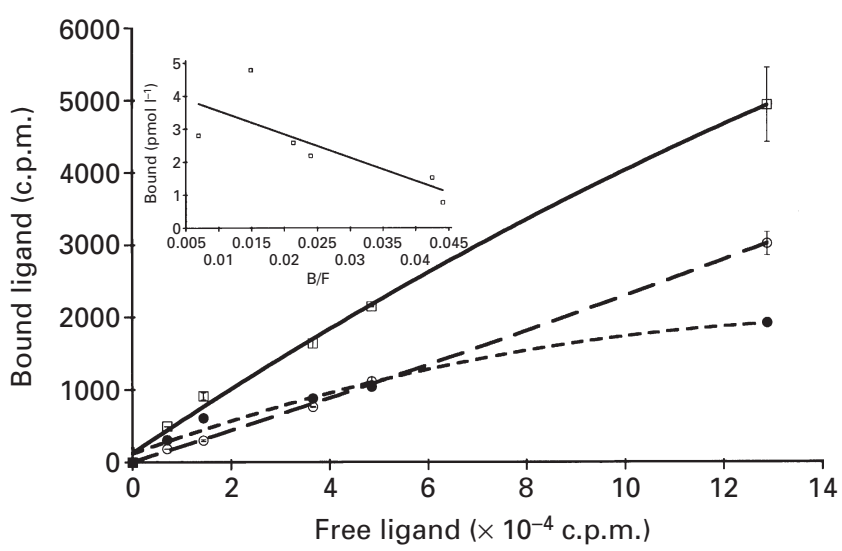

Fig. 4. Representative experiment of equilibrium saturation binding of human relaxin-like factor (RLF) tracer on crude membranes from rat gubernacula from 12-15-day-old male rats. Each data point represents duplicates. $\square$ : Total binding; $\bigcirc$ : nonspecific binding; $\mathbf{0}$ : specific binding. For total and non-specific binding, bars indicate standard errors. Inset: corresponding Scatchard plot. B/F: bound/free. For evaluation of data, three Scatchard analyses were performed and normalized to the protein content. Dissociation constant $K_{\mathrm{D}}: 138 \pm 34.9$ pmol; $B_{\max }=5.67$ $\pm 1.3 \mathrm{pmol} \mathrm{I}^{-1} ; 2.2 \mathrm{fmol}$ RLF receptors per mg membrane protein.

reported previously for human RLF to achieve high sensitivity (Büllesbach and Schwabe, 1995). Unlabelled, mono-iodinated and di-iodinated mouse RLF was separated and the mono-iodination product only was used for these studies. Subsequent investigations have shown that mouse RLF and human RLF tracers are indistinguishable when used for receptor binding studies on crude membranes of mouse or rat tissues.

Antibodies raised in rabbits against synthetic mouse RLF gave rise to a typical sigmoidal binding curve when incubated with increasing concentrations of mouse RLF (Fig. 2). The dose-response curves determined in radioimmunoassay buffer and in the presence of female rat serum are identical, resulting in an $\mathrm{ED}_{50}$ value of $1.1 \pm 0.2 \mathrm{ng}$ $\mathrm{ml}^{-1}$ (Fig. 2). The sensitivity of the assay allows quantitative measurements up to the $\mathrm{ED}_{80}$ value $\left(0.25 \mathrm{ng} \mathrm{ml}^{-1}\right)$. The antiserum is specific for RLF and does not bind to rat relaxin, bovine insulin, IGF-I or mouse RLF A-chain. It binds only very weakly to mouse RLF B-chain (Fig. 2), indicating that it interacts with a non-continuous epitope. When the antibody was used in combination with human RLF tracer, the radioimmunoassay was improved further to an $\mathrm{ED}_{50}$ value of $0.5 \pm 0.1 \mathrm{ng} \mathrm{ml}^{-1}(n=3)$ and the limit of detection was increased to $0.1 \mathrm{ng} \mathrm{ml}^{-1}$. Rat RLF, synthesized according to the recently published cDNA sequence (Spiess et al., 1999), showed a parallel dose-response curve within the critical region. This antibody recognized a natural component in rat sera and was used to determine RLF concentrations in the sera of pre- and postnatal male rats. Circulating RLF concentrations varied sharply with the developmental stage of the pups, showing high serum concentrations at 2 days before birth followed by a sharp decrease 1 day before

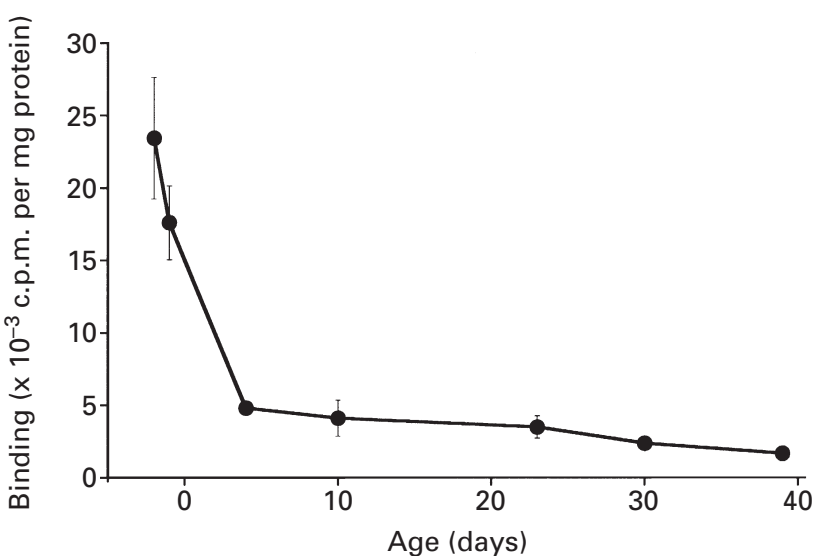

Fig. 5. Relaxin-like factor (RLF) receptor concentrations in crude membrane preparations of rat gubernacula during development. The determination of radioactivity (counts per mg membrane protein) in duplicate in three independent experiments. The data were pooled and the mean \pm SEM is shown.

parturition $(P<0.05)$. The low RLF concentrations persisted up to day 10 after parturition and were followed by a steady increase until day 39 when adult concentrations of $0.6 \mathrm{ng}$ $\mathrm{ml}^{-1}$ were reached (Fig. 3). RLF was barely detectable in the sera of female pups at day 2 before parturition and in postpartum female rats at day 30 .

The next series of experiments was designed to determine whether the gubernaculum carried RLF-specific binding sites. Gubernaculum tissues from 12-15-day-old animals were dissected carefully and used to prepare crude membrane preparations for binding studies. Binding of 125 I-labelled RLF to gubernaculum membranes reached saturation and non-specific binding was linear at about $60 \%$ of total binding (Fig. 4). The results were subjected to Scatchard analysis (inset in Fig. 4) and yielded a dissociation constant of $138 \pm 34.9$ pmol and a $B_{\max }$ of $5.67 \pm 1.3 \mathrm{pmol} \mathrm{I}^{-1}$. There are $2.2 \mathrm{fmol}$ RLF receptors per $\mathrm{mg}$ membrane protein, which is within the order of magnitude reported for RLF and relaxin receptors in mouse uterus (Yang et al., 1992; Büllesbach and Schwabe, 1999a).

Determination of the number of gubernaculum RLF receptors as a function of development showed relatively high concentrations per mg membrane protein at day 2 before parturition, and a sharp decrease after parturition. The number of receptors per $\mathrm{mg}$ of tissue decreased further up to day 39 after parturition, the endpoint of this study (Fig. 5). The question of specificity of receptor distribution was addressed by testing for RLF receptors in the neighbouring inguinal canal and the testis. Inguinal tissues from 4-day-old rats and testis from 30-day-old rats were dissected carefully and membranes were prepared for RLF receptor binding assays. No receptors were found in inguinal tissue and the testis, indicating that the RLF response is limited to the gubernaculum (Table 1).

Cultures of rat gubernaculum cells prepared from collagenase-treated tissues of 3-day-old rats showed specific RLF binding. The complete set of experiments, 
Table 1. Relaxin-like factor (RLF) receptor binding on different male rat tissues

\begin{tabular}{|c|c|c|c|c|}
\hline Tissue & Age (days) & $\begin{array}{l}\text { Total binding } \\
\text { (c.p.m.) }\end{array}$ & $\begin{array}{l}\text { Non-specific binding } \\
\text { (c.p.m.) }\end{array}$ & $P$ value \\
\hline Gubernaculum & 30 & $1671 \pm 51$ & $1240 \pm 45$ & $<0.001$ \\
\hline Gubernaculum cell culture* & $3 * *$ & $2401 \pm 113$ & $1544 \pm 60$ & $<0.001$ \\
\hline Inguinal canal & 4 & $1253 \pm 92$ & $1176 \pm 67$ & ns \\
\hline Testis & 30 & $11835 \pm 446$ & $11102 \pm 188$ & ns \\
\hline
\end{tabular}

Values are mean $\pm \mathrm{SE}$.

Each experiment was performed in triplicate.

*Whole cell assay.

$* *$ Tissue collection for culture.

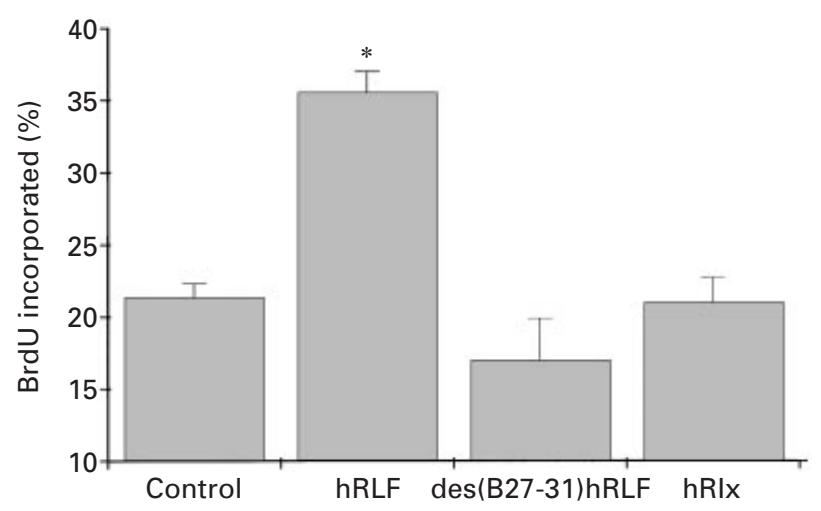

Fig. 6. The uptake of 5-bromo-2'-deoxyuridine (BrdU) in primary cultures of rat gubernaculum cells. Experiments were done in duplicate. The mean \pm SE of a representative experiment is shown. *Only synthetic RLF (hRLF) stimulated BrdU uptake above control values $(P<0.005, n=7)$. des(B27-31)hRLF lacks the major receptor binding residues $(n=3)$ and human relaxin $(\mathrm{hRIx} ; n=3)$ is inactive.

starting with gubernacula, was repeated three times with the same results. One representative experiment indicating that the primary cell culture contains RLF receptor-bearing cells is shown (Table 1). When these cells were exposed to RLF, accelerated BrdU incorporation was observed only in cells that received media containing $1 \mathrm{ng} \mathrm{RLF} \mathrm{m}^{-1}(P<0.005$, $n=7)$. This effect was not observed when human relaxin $(n=3)$ or inactive $(\operatorname{desB}(27-31))$ human $\operatorname{RLF}(n=3)$ was substituted for the intact RLF (Fig. 6).

\section{Discussion}

The mechanisms by which the testes are moved through the abdomen toward the genital region and eventually through the inguinal canal into the scrotum are unclear. However, it is generally accepted that normal testis descent relies on structural changes in the gubernaculum (Hutson et al., 1997). In rats, the gubernaculum develops before birth and before testis migration occurs. It is a mesenchymal structure that extends from the testes located in the middle of the abdominal cavity to the inguinal area and the scrotum. Several changes that occur in the gubernaculum are described by the two-phase model of testicular descent
(Hutson, 1985). Accordingly, outgrowth of the gubernaculum tissue is caused by cell division and by changes in various matrix components. Firstly, the gubernaculum widens to dilate the inguinal canal and then the outgrowth distal to the inguinal canal shortens and pulls the testis towards the inguinal passageway. During the second phase, the gubernaculum undergoes regression, caused mainly by changes in extracellular matrix (Fentener van Vlissingen et al., 1989; Heyns et al., 1990), and the testes pass through the area formerly occupied by the gubernaculum, into the scrotal compartment. RLF plays a crucial role in the overall process (Nef and Parada, 1999; Zimmermann et al., 1999; Adham et al., 2000) and the experiments performed in the present study were designed to investigate the involvement of RLF. Although knockout experiments left no doubt that male mice devoid of RLF develop cryptorchidism, there was no evidence linking RLF directly to the gubernaculum changes or to indicate that the gubernaculum has RLF receptors.

The synthesis of mouse RLF and the murine-specific tracer, as well as the production of a specific antibody, provided powerful tools to explore the role of RLF in testis decent. The binding curve indicates that the radioimmunoassay for RLF is sensitive and specific, which can be attributed in part to HPLC purification of all tracers. While this study was in progress, the rat RLF sequence was published, which showed differences from mouse RLF sequence at positions A2 (Ala/Val) and B17 (Ala/Thr) (Spiess et al., 1999). Rat RLF was synthesized in the present study and in the heterologous assay it was confirmed that both mouse and rat RLF produce dose-response curves that are parallel within the critical region.

High RLF concentrations were detected by radioimmunoassay in sera from male rat fetuses at day 2 before parturition; this may be preparatory, a trigger event for the development of the gubernaculum (at day 2 before parturition females have very low serum RLF concentrations). RLF decreases to very low concentrations at birth, indicating that the prepartum increase in RLF concentration may be physiologically important. Furthermore, the movement of testes and the descent into the scrotum are completed before RLF concentrations increase again in adult rats, indicating that postpartum RLF concentrations are not critical for testicular positioning. This 'critical time' 
hypothesis would explain why human males with a history of cryptorchidism usually have normal adult RLF serum concentrations (C. Schwabe, unpublished). In future, testing of newborns for RLF concentrations may shed light on this observation. Clearly, other factors, such as the RLF receptor, may contribute to cryptorchidism in humans and our experimental system provides a method to elucidate these factors.

RLF receptors are very prominent in the differentiating gubernaculum tissue as early as they can be detected. The initial display of receptors also supports the contention that the prenatal serum RLF concentrations may have provided the crucial starting signal for gubernaculum growth in preparation for testicular migration. Further support comes from gene deletion experiments, which show that the gubernaculum in $\mathrm{RLF}^{-/-}$animals does not even begin to undergo organization (Nef and Parada, 1999; Zimmermann et al., 1999). Finally, our observation of high prenatal RLF serum concentrations supports the results of experiments showing that RLF mRNA is expressed at high concentrations in the testes of rat embryos (Spiess et al., 1999).

The binding constant for rat gubernaculum receptor was within the same order of magnitude as that of mouse uterine RLF receptor (Büllesbach and Schwabe, 1999a). At an infinite concentration of free ligand there appears to be 2.2 fmol receptor per mg membrane protein, which compares well with about $7 \mathrm{fmol} \mathrm{mg}^{-1}$ uterine tissue (Büllesbach and Schwabe, 1999a). Transiently active hormones such as relaxin and RLF appear to have significantly fewer receptors in their target tissues than does, for example, insulin.

Experiments involving BrdU indicate that RLF may have a mild growth factor activity, which is not unexpected given that the first phase of gonadal movement is associated with induction and growth of the gubernaculum. A similar observation was made by Emmen et al. (2000), who described an increasing ${ }^{3}[\mathrm{H}]$ thymidine uptake in rat gubernaculum cocultured with testis of $\mathrm{RLF}^{+/}$mice, whereas testis of $\mathrm{RLF}^{-/-}$mice did not show this effect. In the present study, the increase in BrdU incorporation was significantly higher in the presence of RLF than in controls which received medium only, medium with relaxin or medium with an inactive form of RLF that lacks the major binding residues (Büllesbach and Schwabe, 1999b). An additional point is that it now seems likely that the hormone affects the gubernaculum directly and that the process may be orchestrated by critical timing of Leydig cell activity.

The authors would like to thank S. Frawley for providing critical support for this work. This work was supported by National Institute of Health Grant 1-R01-HD40406-01 and by the United States Department of Agriculture Grant SCR-1 999-03614.

\section{References}

Adham IM, Burkhardt E, Benahmed M and Engel W (1993) Cloning of a CDNA for a novel insulin-like peptide of the testicular Leydig cells Journal of Biological Chemistry 26826 668-26 672

Adham IM, Emmen JMA and Engel W (2000) The role of the testicular factor
INSL3 in establishing the gonadal position Molecular and Cellular Endocrinology $16011-16$

Bathgate R, Balvers M, Hunt N and Ivell R (1996) Relaxin-like factor gene is highly expressed in the bovine ovary of the cycle and pregnancy sequence and messenger ribonucleic acid analysis Biology of Reproduction 55 1452-1457

Büllesbach EE and Schwabe C (1991) Total synthesis of human relaxin and human relaxin derivatives by solid phase peptide synthesis and sitedirected chain combination Journal of Biological Chemistry 266 $10754-10761$

Büllesbach EE and Schwabe C (1995) A novel Leydig cell cDNA-derived protein is a relaxin-like factor (RLF) Journal of Biological Chemistry $\mathbf{2 7 0}$ 16 011-16015

Büllesbach EE and Schwabe C (1996) The chemical synthesis of rat relaxin and the unexpectedly high potency of the synthetic hormone in the mouse European Journal of Biochemistry 241 533-537

Büllesbach EE and Schwabe C (1999a) Specific, high-affinity relaxin-like factor receptors Journal of Biological Chemistry 27422 354-22 358

Büllesbach EE and Schwabe C (1999b) Tryptophan B27 in the relaxin-like factor (RLF) is crucial for RLF receptor binding Biochemistry 38 3073-3078

Büllesbach EE, Rhodes R, Rembiesa B and Schwabe C (1999) The relaxinlike factor is a hormone Endocrine 10 167-169

Burkhardt E, Adham IM, Brosig B, Gastmann A, Mattei MG and Engel W (1994) Structural organization of the porcine and human genes coding for a Leydig cell-specific insulin-like peptide (LEY I-L) and chromosomal localization of the human gene (INSL3) Genomics 20 13-19

Emmen JMA, McLuskey A, Adham IM, Engel W, Grootegoed JA and Brinkmann AO (2000) Hormonal control of gubernaculum development during testis descent: gubernaculum outgrowth in vitro requires both insulin-like factor and androgens Endocrinology 141 $4720-4727$

Fentener van Vlissingen JM, Koch CAM, Delpech B and Wensing CJG (1989) Growth and differentiation of the gubernaculum testis during testicular descent in the pig: changes in the extracellular matrix, DNA content, and hyaluronidase, $\beta$-glucuronidase, and $\beta-\mathrm{N}$ acetylglucosaminidase activities Journal of Urology 142 837-845

Heyns CF, Human HJ, Werely CJ and DeKlerk DP (1990) The glycosaminoglycans of the gubernaculum during testicular descent in the fetus Journal of Urology 143 612-617

Hunter WM and Greenwood FC (1962) Preparation of iodine-131 labelled human growth hormone of high specific activity Nature 194 495-496

Hutson JM (1985) A biphasic model for the hormonal control of testicular descent Lancet 2 419-421

Hutson JM, Hasthorpe S and Heyns CF (1997) Anatomical and functional aspects of testicular descent and cryptorchidism Endocrine Reviews $\mathbf{1 8}$ 259-280

John Radcliffe Hospital Cryptorchidism Study Group (1986) Cryptorchidism: an apparent substantial increase since 1960 British Medical Journal 293 1401-1404

Markwell MAK, Haas SM, Tolbert NE and Bieber LL (1981) Protein determination in membrane and lipoprotein samples: manual and automated procedures Methods in Enzymology 72 296-303

Møller H, Prener H and Skakkebæk NE (1996) Testicular cancer, cryptorchidism, inguinal hernia, testicular atrophy, and genital malformations: case control studies in Denmark Cancer Causes and Control 7 264-274

Nef S and Parada LF (1999) Cryptorchidism in mice mutant for Insl3 Nature Genetics 22 295-299

Pike MC, Chilvers C and Peckham MJ (1986) Effect of age at orchidopexy on risk on testicular cancer Lancet I 1246-1248

Pusch W, Balvers M and Ivell R (1996) Molecular cloning and expression of the relaxin-like factor from the mouse testis Endocrinology 137 3009-3013

Roche PJ, Butkus A, Wintour EM and Tregear G (1996) Structure and expression of Leydig insulin-like peptide mRNA in the sheep Molecular and Cellular Endocrinology 121 171-177

Scatchard G (1949) The attraction of proteins for small molecules and ions Annals of the New York Academy of Sciences 51 660-672 
Scorer CG (1964) The descent of the testis Archives of Disease in Childhood 39 605-609

Spiess AN, Balvert M, Tena-Sempere M, Huhtaniemi I, Parry L and Ivell R (1999) Structure and expression of the rat relaxin-like factor (RLF) gene Molecular Reproduction and Development 54 319-325

Strader CH, Weiss NS, Daling JR, Karagas MR and McKnight B (1988) Cryptorchidism, orchiopexy, and risk of testicular cancer American Journal of Epidemiology 127 1013-1018

Tashima LS, Hieber AD, Greenwood FC and Bryant Greenwood GD (1995) The human Leydig insulin-like (hLEY I-L) gene is expressed in the corpus luteum and trophoblast Journal of Clinical Endocrinology and Metabolism $80707-710$

Toppari J and Kaleva M (1999) Maldescendus testis Hormone Research 51 261-269

Visser JH and Heyns CF (1995) Proliferation of gubernaculum cells induced by a substance of low molecular mass obtained from fetal pig testes Journal of Urology 153 516-520

Whitaker R (1988) Neoplasia in cryptorchid men Seminars in Urology 6 78-83
Yang S, Rembiesa B, Büllesbach EE and Schwabe C (1992) Relaxin receptors in mice: demonstration of ligand binding in symphyseal tissues and uterine membrane Endocrinology 130 179-185

Zimmermann S, Schottler P, Engel W and Adham IM (1997) Mouse Leydig insulin-like (Ley I-L) gene - structure and expression during testis and ovary development Molecular Reproduction and Development 47 30-38

Zimmermann S, Steding G, Emmen JMA, Brinkmann AO, Nayernia K Holstein AF, Engel W and Adham IM (1999) Targeted disruption of the Insl3 gene causes bilateral cryptorchidism Molecular Endocrinology 13 681-691

Received 23 April 2001

First decision 31 May 2001.

Final revision received 13 August 2001.

Accepted 23 August 2001. 